\title{
Gestational Diabetes Mellitus: A Harbinger of the Vicious Cycle of Diabetes
}

\author{
Emilyn U. Alejandro ${ }^{1, *}$, Therriz P. Mamerto ${ }^{2,3}$, Grace Chung ${ }^{1}$, Adrian Villavieja ${ }^{2,3}$, \\ Nawirah Lumna Gaus ${ }^{3}$, Elizabeth Morgan ${ }^{4}$ and Maria Ruth B. Pineda-Cortel $2,3,5, *$ (1) \\ 1 Department of Integrative Biology and Physiology, Medical School, University of Minnesota, \\ Minneapolis, MN 55455, USA; chung491@umn.edu \\ 2 Research Center for the Natural and Applied Sciences, University of Santo Tomas, Manila 1015, Philippines; \\ tpmamerto@ust.edu.ph (T.P.M.); adrian.e.villavieja@gmail.com (A.V.) \\ 3 The Graduate School, University of Santo Tomas, Manila 1015, Philippines; gausnawirahl@gmail.com \\ 4 Baystate Medical Center, Baystate Health, Springfield, MA 01199, USA; lizzmorg@gmail.com \\ 5 Department of Medical Technology, Faculty of Pharmacy, University of Santo Tomas, \\ Manila 1015, Philippines \\ * Correspondence: ealejand@umn.edu (E.U.A.); mbpineda-cortel@ust.edu.ph (M.R.B.P.-C.); \\ Tel.: +1-(612)-301-7685 (E.U.A.); +63-917-8211931 (M.R.B.P.-C.)
}

Received: 3 June 2020; Accepted: 13 July 2020; Published: 15 July 2020

\begin{abstract}
Gestational diabetes mellitus (GDM), characterized by a transitory form of diabetes induced by insulin resistance and pancreatic $\beta$-cell dysfunction during pregnancy, has been identified as one of the major obstacles in achieving improved maternal and child health. Approximately $9-25 \%$ of pregnancies worldwide are impacted by the acute, long-term, and transgenerational health complications of this disease. Here, we discuss how GDM affects longstanding maternal and neonatal outcomes, as well as health risks that likely persist into future generations. In addition to the current challenges in the management and diagnosis of and the complications associated with GDM, we discuss current preclinical models of GDM to better understand the underlying pathophysiology of the disease and the timely need to increase our scientific toolbox to identify strategies to prevent and treat GDM, thereby advancing clinical care.
\end{abstract}

Keywords: gestational diabetes mellitus and diabetes; polycystic ovary syndrome; obesity; fetal programming; type 2 diabetes; hyperglycemia; glycemic control; insulin; pregnancy complications; diabetes animal models; placenta

\section{Introduction}

Improving maternal health and reducing childhood mortality are two of the United Nation's eight Millennium Development Goals (MDGs). They represent a unique and daunting challenge for healthcare providers worldwide [1,2]. The MDGs are supported by organizations such as the International Federation of Gynecology and Obstetrics (FIGO), which focuses its efforts on the reduction of non-communicable maternal diseases (NCDs) and exposures in pregnancy to improve the future health of women and their offspring. Specifically, FIGO is targeting hyperglycemia, obesity, hypertension, and poor nutrition in pregnancy to reduce the development of diseases later in life, such as obesity and type 2 diabetes mellitus (T2D). This is important, as the goals of early intervention are not only to improve future maternal health but also to reduce disease prevalence in subsequent generations [2].

Pregnancy is often described as a "window" to future health [3], since the physiologic changes that occur during this time act as a natural "stress test" for the body. Many women seek medical care during 
their pregnancy, which makes this an opportune time for preventive healthcare guidance. In recent years, there has also been a growing realization that the intrauterine environment (e.g., the maternal nutritional status) influences the health of offspring throughout their lifespan $[4,5]$. The emerging field of the developmental origins of health and disease (DOHAD) posits that intrauterine and early infant environments have a permanent conditioning or programming effect on the body's metabolism and health later in life.

One common physiological change that can occur during pregnancy is the development of glucose intolerance causing hyperglycemia. This is referred to as gestational diabetes mellitus (GDM). The pathophysiology of GDM is not fully understood but has been linked to hormonal imbalances affecting insulin sensitivity and pancreatic $\beta$-cell dysfunction [6]. It is estimated that one in every six pregnancies worldwide is associated with hyperglycemia, $84 \%$ of which are classified as GDM [2]. GDM is an important determinant of the development of T2D in both mothers and their offsprings, and thus, achieving glycemic control during pregnancy may provide a window of opportunity to prevent and lower the burden of T2D in many generations.

The goal of this review is to elaborate on how peripartum nutrition affects longstanding maternal and neonatal outcomes, as well as health risks that likely persist into future generations. We aim to summarize current knowledge and data on GDM, with a specific emphasis on screening, diagnosis, and peripartum complications and preclinical models of the disease. Understanding risk factors and improving diagnosis will allow earlier identification and intervention, with the goal of preventing future complications.

\section{Gestational Diabetes Mellitus}

GDM, defined as glucose intolerance with onset or first recognition during pregnancy [7], is a common antepartum condition impacting about $9-25 \%$ of pregnancies worldwide [8,9], with rates fluctuating depending on study populations and diagnostic criteria. GDM is characterized by impaired glucose tolerance as a result of maternal pancreatic $\beta$-cell dysfunction, resulting in the insufficiency of insulin to regulate glucose homeostasis during pregnancy [10].

Insulin, an anabolic hormone released by the $\beta$-cells in the pancreas, modulates glucose homeostasis by stimulating glucose uptake into peripheral tissues, inhibiting glucose production by the liver, and suppressing stored lipid release from the adipose tissue. Insulin resistance is a state in which normal concentrations of insulin fail to achieve an appropriate biological response downstream of the insulin receptor. As a result, the $\beta$-cells have to release more insulin than usual to regulate maternal blood glucose levels. In a healthy pregnancy, a condition of progressive insulin resistance occurs in the mother, triggered by placental hormones to ensure the fetus receives adequate nutrients for healthy growth and development. In order to maintain glucose homeostasis despite insulin resistance, the maternal $\beta$-cells compensate by increasing total cell number, insulin synthesis, and insulin secretion [11]. However, when the maternal $\beta$-cells are unable to adapt to the metabolic changes accompanying pregnancy, hyperglycemia of GDM occurs.

\section{Risk Factors for GDM}

\subsection{Modifiable Risk Factors}

\subsubsection{Overweight, Obesity, and Pre-Pregnancy Body Mass Index (BMI)}

During pregnancy, maternal dyslipidemia is a physiological response that provides fuel and nutrients for both the placenta and the developing fetus [12]. It is not unusual to observe weight gain in pregnancy, marked by deposition and hypertrophy of adipocytes in the maternal adipose tissue [13]. While pregnant mothers are expected to gain about $30 \%$ of their gestational weight in body fat [14], overweight and obesity are the most associated risk factors for GDM [15]. Pre-pregnancy BMI alone is an important risk factor for GDM [16]. The World Health Organization (WHO) defines 
overweight and obesity as an abnormal or excessive fat accumulation based on BMI $>25 \mathrm{~kg} / \mathrm{m}^{2}$ or $>30 \mathrm{~kg} / \mathrm{m}^{2}$, respectively. Given the current epidemic of obesity and the increased rate of obesity in child-bearing women, it is estimated that there are 38.9 million overweight and 14.6 million obese pregnant women worldwide [17]. For people who are overweight and obese, increased lipid production leads to the accumulation of lipids, mainly triglycerides, in the adipose tissue and other organs, such as the liver. Hepatic insulin resistance is increased in obesity and is further exacerbated by pregnancy, thus increasing the risk of developing GDM [18]. Moreover, being overweight or obese during pregnancy can increase the risk of adverse consequences such as metabolic disorders: hypertension [19], premature delivery [20], and stillbirth [21,22], as well as others [23]. For these reasons, obstetricians regularly assess the BMI and gestational weight gain of pregnant women [24] in order to prevent complications for both mother and child. The current prevention strategies to manage body weight during pregnancy include nutritional therapy and improving dietary and lifestyle habits [25-27].

\subsubsection{Metabolic Syndrome and Nutritional Diet}

The term metabolic syndrome was first used by the National Cholesterol Education Program Adult Treatment Panel III to describe the clustering occurrence of metabolic disorders such as obesity, dyslipidemia, hypertension, and abnormal glucose metabolism under one common condition. Metabolic syndrome when accompanied by a western-style diet high in sweets, fats, and processed foods, is known to increase the occurrence of GDM [28-32]. In addition, vitamin D deficiency and high dietary acid load may also contribute to the risk of GDM [33].

Notably, the first line of prevention or treatment for metabolic syndrome is nutritional diet therapy, which has been shown to be beneficial in maintaining glucose control and physiologic health [34-36]. Nutritional therapies, such as high-fiber and low-glycemic-index diets, have been shown to improve insulin sensitivity and glucose tolerance, which may reduce the risk for GDM [37-42]. Recent literature has also shown the benefits of probiotic therapy in improving blood glucose levels by targeting the gut microbiota [43-45]. Finally, anti-hyperglycemic medications, such as insulin therapy and metformin, can be introduced when lifestyle modifications alone are not sufficient to achieve glycemic control [46].

\subsubsection{Polycystic Ovary Syndrome (PCOS)}

GDM and polycystic ovary syndrome (PCOS) are the most common endocrine disorders in women of reproductive age. PCOS is a heterogeneous endocrine and metabolic disorder characterized by chronic oligomenorrhea [47], hyperandrogenism [48], and insulin resistance [49]. Like GDM, PCOS is associated with insulin resistance and obesity [50]. While the risk for GDM increases for women with PCOS in the presence of other comorbidities, such as obesity and increased maternal age, PCOS per se is not an independent risk factor for GDM [51,52]. In a prevalence study in California, data showed that pregnant women with PCOS have more than a twofold risk for GDM compared with women without PCOS or related symptoms [53]. Indeed, the prevalence of PCOS is higher in women with GDM than in non-diabetic women [51]. PCOS is often associated with metabolic syndrome, and common prevention strategies include lifestyle modification [54,55] and pharmacological treatments [56].

\subsubsection{Pre-Eclampsia}

Pre-eclampsia is a common hypertensive disorder that occurs in $2-8 \%$ of all pregnancies worldwide [57,58]. Like GDM, pre-eclampsia is linked to glucose intolerance, hyperglycemia, and obesity [59]. Hyperglycemia is known to increase the risk of pre-eclampsia [60-62]. In subsequent pregnancies, pre-eclampsia is an independent risk factor for GDM [61].

\subsubsection{Additional Modifiable Risk Factors for GDM}

A few studies have determined that prolonged exposure to environmental psychological stress is related to maternal hyperglycemia during pregnancy, which may increase the risk of GDM [63]. 
Similarly, the use of antidepressant and psychotropic medications, smoking, and poor sleep hygiene have also been shown to be risk factors for GDM [64-66].

\subsection{Non-Modifiable Risk Factors}

\subsubsection{Maternal Age}

Maternal age is a common risk factor for GDM. Studies have shown that maternal age above 25-30 years increases the risk of developing GDM [67-70]. In a meta-analysis study investigating the relationship between maternal age and the risk of GDM, authors identified a linear relationship between the risk for GDM and increasing maternal age. It was also indicated that for every successive year after the age of 18 , the risk for GDM increases by $7.90 \%, 12.74 \%$, and $6.52 \%$ in the general, Asian, and Europid populations, respectively [71].

\subsubsection{Gravidity and Parity}

Increasing gravidity, defined as the number of times that a woman has been pregnant, and parity, i.e., the number of times that she has given birth, may represent an additional risk for GDM [69]. This elevated risk of developing GDM has been linked to parities as low as two [67,72]. The effect of gravidity on the risk of GDM has been associated with increasing age as well, since an increased number of pregnancies is observed in women with advanced maternal age [73].

\subsubsection{Ethnicity}

Several studies have linked GDM development with ethnicity. Increased risk of GDM is seen in multiple ethnic and racial groups, including Hispanic, African American, and Asian women [73,74]. Women of Korean, Chinese, and Filipino descent are more than twice as likely to develop GDM as Caucasian or African American women [75]. Although the mechanisms remain unclear, possible explanations can arise from health predisposition, lifestyle, cultural factors, and socioeconomic stressors [71,73]. In regards to T2D studies, South Asians have been reported to have reduced fat metabolism, muscle fitness, insulin sensitivity, and insulin secretion, all of which support a higher tendency towards glucose intolerance [76,77]. Taking ethnicity as a risk factor for GDM, it is therefore important for health providers to recognize that certain ethnic groups may benefit from special preventive and culturally sensitive care. Further, structural changes, such as combatting systemic racism and bias are necessary to break down disparities associated with these preventable NCDs.

\subsubsection{Genetics and Family History of Hyperglycemia}

GDM is a multifactorial disease with both genetic and environmental influences. A family history of diabetes is an important independent risk factor for the development of GDM [78]. There is a strong association between common T2D risk gene polymorphisms and GDM [79]. Five of the most identified genes in GDM are: (1) Transcription factor 7-like 2 [TCFL7L2] [80,81]; (2) Melatonin receptor 1B [MTNR1B] [82,83]; (3) CDK5 regulatory subunit-associated protein 1-like 1 [CDKAL1] [84,85]; (4) Potassium voltage-gated channel, KQT-like subfamily, member 1 [KCNQ1] [86,87]; and (5) Insulin receptor substrate-1 [IRS1] [88,89]. The most recent and comprehensive searches in the genetic and epigenetic etiology of GDM have been reviewed elsewhere [90,91]. These epigenetic modifications may result in maternal and paternal transgenerational inheritance of obesity and glucose intolerance in the offspring [92-94]. Moreover, the types of genetic variation and the mechanisms of epigenetics may contribute to genotypic and phenotypic characteristics in different ethnicities $[95,96]$. For example, studies that explored the relationship between ethnicity and GDM revealed that Asian women have the highest GDM incidence [97,98]. The variability in the association of genetic polymorphisms and risk of GDM has been attributed to ethnicity or population differences; thus, there is a need to perform population-dependent studies on the effect of genetic polymorphisms on the risk of GDM $[99,100]$. 


\subsection{Socioeconomic and Geographic Risk Factors}

\subsubsection{Climate and Geographical Location}

The WHO recognizes that varying climate conditions from extreme winter temperatures to summer temperatures have an impact on human health. There is increasing evidence showing the influence of temperature on physiologic mechanisms such as the regulation of fats and lipids [101,102], energy expenditure, hormonal homeostasis [103], myocardial infarction [104], and mortality [105]. Climate also appears to have an effect on GDM. In regions with seasonal weather changes there is a higher prevalence of GDM than in more temperate regions of the world [106].

\subsubsection{Education and Socio-Economic Status}

Based on observational studies, many women diagnosed with GDM are unaware of the risk factors and complications of their diagnosis [107-109]. A study in Finland reported that there was an inverse relationship between socioeconomic status and GDM [110]. This is supported by findings that patients who are uninsured and underinsured receive less preventive healthcare, with some receiving little or no healthcare at all $[111,112]$. To improve the efficacy of GDM treatment, promoting health education combined with government support to patients is an important component of prenatal care [113]. Several strategies shown to be beneficial in promoting awareness of GDM and improving pregnancy outcomes include the use of web-based education [97] and/or of individual or group educational sessions with a healthcare provider or a dietician [114-116].

\subsection{Screening and Diagnosis}

\subsubsection{Laboratory Evaluation}

To fully address the increasing prevalence of GDM worldwide, routine screening for GDM during prenatal care is necessary. However, only few countries routinely test pregnant women universally. In the United States, the American College of Obstetricians and Gynecologists (ACOG) recommends all pregnant women be tested in the mid-trimester (between 24 and 28 weeks of gestation) [117]. In some countries, testing is completed based on the risk assessment done by the Obstetrician-Gynecologist. Risk is categorized by doctors as low, average, or very high. Low-risk individuals are those whose age is below 25 years, with normal pre-pregnancy weight, members of an ethnic group with a low prevalence of diabetes, no known diabetes in first-degree relatives, no history of abnormal glucose tolerance, and no history of poor obstetric outcomes.

Although there is no international, standardized consensus on the screening test to be used, the oral glucose tolerance test (OGTT) is commonly utilized $[118,119]$. There are two current approaches for testing GDM. In the one-step approach, a single $75 \mathrm{~g}$ OGTT is conducted, while in the two-step approach, an initial screening using a $50 \mathrm{~g}$ oral glucose challenge test (OGCT) is performed; if the results of this test show a glucose value equal or greater than $7.7 \mathrm{mmol} / \mathrm{L}(130-140 \mathrm{mg} / \mathrm{dL})$ [117], the pregnant woman analyzed should undergo a confirmatory $100 \mathrm{~g}$ OGTT several days after the OGCT [120-122]. Table 1 below shows the comparison between the one-step approach and the two-step approach.

Numerous studies have evaluated these screening modalities. One study compared the prevalence and pregnancy outcomes of Thai GDM patients screened using the one-step, $75 \mathrm{~g}$ OGTT and the two-step approach. The results showed a very high prevalence of GDM when the one-step approach was utilized; however, there was no clear evidence of better performance of this test. This higher prevalence seen using the one-step approach was associated with the use of a lower threshold for diagnosis, which thus led to an increased sensitivity [123]. A higher sensitivity may result in an increased number of false positives and overdiagnosis and treatment, with increased risk of unnecessary intervention, higher costs, and decreased maternal satisfaction with testing and prenatal care [125]. The two testing approaches present advantages and disadvantages. While the one-step approach has a lower economic burden and a lower threshold, allowing for the earlier diagnosis of milder disease and 
possible early prevention of complications in the mother and baby $[124,126]$, the two-step approach is less convenient economically and requires more time for diagnosis, though it still provides diagnostic efficacy [127].

Table 1. Advantages and disadvantages of the one-step and two-step approaches of glucose testing [120-124]. GDM, gestational diabetes mellitus, Neonatal Intensive Care Unit (NICU), OGTT, oral glucose tolerance test.

\begin{tabular}{|c|c|c|}
\hline Type of Testing & Advantages & Disadvantages \\
\hline One-step approach & $\begin{array}{c}\text { Simple to follow } \\
\text { Better patient adherence } \\
\text { Easy diagnosis } \\
\text { Cost-effective for high-risk individuals } \\
\text { Increased sensitivity } \\
\text { Detection of milder GDM, thus less } \\
\text { complications like pre-eclampsia, applicable } \\
\text { to women of any gestational age, neonatal } \\
\text { hypoglycemia, neonatal death, and NICU } \\
\text { admission }\end{array}$ & $\begin{array}{l}\text { Poor reproducibility } \\
\text { Women need to be in a fasting state }\end{array}$ \\
\hline Two-step approach & $\begin{array}{l}\text { Fewer false positive results } \\
\text { Avoids OGTT in more than } 75 \% \text { of women }\end{array}$ & $\begin{array}{l}\text { Less patient compliance } \\
\text { Requires patients to make two visits } \\
\text { for testing } \\
\text { Missed diagnosis: } 75 \% \text { sensitivity with } \\
84 \% \text { specificity as compared with the } \\
\text { single-step, } 100 \mathrm{~g} \text { OGTT } \\
\text { Delay in initiating treatment even for } \\
\text { those who tested positive }\end{array}$ \\
\hline
\end{tabular}

\subsubsection{Criteria for GDM Diagnosis}

The selection criteria for the diagnosis of GDM are controversial because of issues in determining the standard reference intervals for GDM diagnosis. The standardization of global criteria is a challenge because GDM is influenced by genetics, ethnicity, and socioeconomic and societal factors. The following health professional and study groups have proposed their own diagnostic criteria: American Diabetes Association (ADA) (187); WHO; International Association of Diabetes and Pregnancy Study Group (IADPSG) (184,186); Australasian Diabetes in Pregnancy Society (ADIPS) [128]; Diabetes Canada [129]; German Association for Gynecology and Obstetrics (DGGG) [130]; Istituto Superiore di Sanità (ISS) [131]; Hyperglycemia and Adverse Pregnancy Outcomes (HAPO) Study Cooperative Research Group [128,132-135]; and The Swiss Society for Endocrinology and Diabetes [136]. Table 2 below shows the most common diagnostic criteria utilized for GDM diagnosis. Varying criteria for diagnosis must be considered, as they may affect the stated prevalence and outcomes of GDM.

Table 2. Commonly used diagnostic criteria for GDM [118,137]. ADA, IADPSG.

\begin{tabular}{cccc}
\hline 75-g OGTT & \multicolumn{2}{c}{ Glucose Threshold for Diagnosing GDM in mmol/L (mg/dL) } \\
\hline GLUCOSE MEASURE & ADA ** & IADPSG * & WHO * \\
FASTING & $5.1(92.0)$ & $5.1(\geq 92.5)$ & $5.1-6.9(92.0-125.0)$ \\
$1 \mathrm{H}$ & $10.0(180.0)$ & $10.0(\geq 180.0)$ & $\geq 10.0(180.0)$ \\
$2 \mathrm{H}$ & $8.5(152.0)$ & $8.5(\geq 153.0)$ & $8.5-11.0(153.0-199.0)$ \\
\hline
\end{tabular}

Legend: * any one value meeting the threshold leads to a diagnosis of GDM; ** any two values meeting the threshold lead to a diagnosis of GDM.

\subsection{Complications}

GDM is characterized by hyperglycemia diagnosed during pregnancy, caused by or compounded with underlying mechanisms such as genetic predisposition, insulin resistance, and chronic inflammation. Although the condition is usually transient, it is a risk factor for the development of T2D 
later in life and may also lead to long-term adverse effects in both mother and offspring. This session enumerates the possible metabolic and physical changes resulting from GDM development.

\subsubsection{Maternal Complications}

In GDM, hyperglycemia may damage endothelial cells, which can result in vascular dysfunction [138] associated with hypertension [139]. Because of this, it is has been suggested that GDM increases the incidence of hypertension during pregnancy and the postpartum period [140]. Both diabetes and hypertension are risk factors for the development of pre-eclampsia, a disorder which affects between $3 \%$ and $5 \%$ of pregnancies worldwide and is characterized by high blood pressure and proteinuria [141,142].

Although hyperglycemia during pregnancy usually resolves after delivery, prolonged insulin resistance and $\beta$-cell dysfunction can also be observed in GDM patients, persisting beyond pregnancy [143]. Because of this, women with previously diagnosed GDM have an increased risk of developing T2D later in life [144-148], with a risk high as 50\% [149]. Also, women who have developed GDM in previous pregnancies may experience a recurrence of GDM in subsequent pregnancies $[150,151]$. For this reason, all women who carry a diagnosis of GDM should have a $2 \mathrm{~h}$ glucose tolerance test at their 6-week post-partum visit [117].

\subsubsection{Fetal Complications}

The developing fetus has a limited ability to produce glucose; therefore, it derives most of its glucose from maternal blood. Maternal glucose crosses the placenta, while maternal insulin does not. As a result, according to the modified Pedersen's hypothesis, if maternal glucose levels are high and uncontrolled, the excess glucose transported through the placenta induces increased fetal insulin production regardless of glucose stimulation [152]. This is supported by the observed increase in the expression of glucose transport proteins (GLUTs) in the placenta in pregnancies affected by insulin-dependent diabetes mellitus [153]. Insulin can also stimulate mTOR, a potent regulator of cell growth [154]. An increase of placental mTOR activity due to increased maternal insulin results in increased cell proliferation and nutrient transport to the fetus via System A and System L amino acid transporters in the placenta $[155,156]$. Hart et al. reviewed the role of mTOR as a nutrient sensor in fetal growth [157].

Because of the aforementioned factors seen in GDM, maternal hyperglycemia and hyperinsulinemia can lead to similar changes in the fetus [158,159], which can contribute to neonatal adiposity [160]. Excess nutrient storage results in an increase in neonatal size at birth, or macrosomia. Between $15 \%$ and $45 \%$ of GDM pregnancies result in macrosomic infants [152], with the bulk of adiposity concentrated around the fetal abdomen and shoulders, increasing the risk for shoulder dystocia and birth trauma [161]. The presence of GDM, coupled with other risk factors like hypertension and obesity during pregnancy, may also lead to preterm labor and birth [162], a prevalence that reaches about $10.6 \%$ worldwide [163].

\subsubsection{Neonatal Complications}

Neonatal complications include possible asphyxia, hypoglycemia, kernicterus and jaundice, bacterial infections, neonatal respiratory distress syndrome (NRDS), and birth trauma, including shoulder dystocia and injury to the brachial plexus [152]. Neonatal hypoglycemia occurs as a result of the abrupt cessation of the maternal source of glucose at birth [164]. This is exacerbated by fetal hyperinsulinemia due to GDM and requires extensive treatment and care if the hypoglycemia persists [165].

\subsubsection{Childhood and Adulthood Complications}

The association between GDM and hyperglycemia in the offspring is well established. In the United States, the study of the Pima Indians provided initial evidence that maternal hyperglycemia 
could lead to adult disease in the offspring. Several epidemiological studies demonstrated the Pima Indian population as having the highest prevalence of T2D among children and adults [166]. Indeed, the offspring of diabetic mothers are more often prone to obesity, hypertension, and dyslipidemia later in life [167]. The Hyperglycemia and Adverse Pregnancy Outcome (HAPO) study in 10 countries revealed that maternal hyperglycemia during pregnancy was significantly associated with an increase in hyperglycemia and insulin resistance in the offspring in adulthood [168]. Markers for insulin resistance, like HOMA-IR, BMI, waist circumference, and triglyceride levels, were also at higher levels in GDM offspring than in those born to normoglycemic mothers $[169,170]$. Presumably, the development of insulin resistance increases the risk of the offspring to develop diabetes, with approximately $20 \%$ of GDM offspring developing T2D and prediabetes by age 22 [171,172].

The increased development of obesity observed in the offspring of mothers with GDM is also associated with an increased risk of metabolic disorders including cardiovascular diseases and insulin resistance [173]. Children born to GDM mothers were observed to have significantly higher blood pressure and adiposity, along with hyperglycemia and BMI [174,175]. As a result of increased cardiovascular risk, GDM offspring are more likely to develop cardiac arrhythmias and be hospitalized for cardiovascular diseases (CVDs) [176]. GDM offspring are also 29\% more likely to develop early-onset CVDs such as heart failure, hypertensive disease, deep vein thrombosis, and pulmonary embolism [177]. All of these studies point to the influence of the environment in utero in the programming of metabolic disease in the offspring. This is an important factor to consider, because overnutrition, physical inactivity, and/or genetic factors alone are not sufficient to explain the current epidemic increases in T2D and obesity. Monterio et al. reviewed the mechanisms of fetal programming in GDM elsewhere [178].

\section{Preclinical Models of GDM}

To stop the vicious cycle of diabetes, we need a greater understanding of the pathophysiology of GDM and the mechanisms of fetal programming induced by GDM. As previously mentioned, this is an essential endeavor, because GDM confers short- and long-term health risks for the mother and the fetus, with potential long-term health consequences in childhood and adulthood [179]. However, establishing causality is difficult in human and epidemiological studies, which are often complicated by confounding multiple factors. Therefore, experimental animal models are critical to study the underlying mechanisms and pathophysiology of GDM. Methods for generating animal models of GDM are diverse and include the surgical removal of all or part of the pancreas, the use of pharmacological agents, diet-induced strategies, and genetic models [180].

\subsection{Surgical Models}

Surgical models include partial or total pancreatectomy, directly reducing the availability of pancreatic $\beta$-cells and dramatically impairing glucose homeostasis [180]. One study performed pancreatectomy in a rat model to reduce the pancreatic mass by $95 \%$, resulting in uterine dysfunction in pregnant rats with mild GDM [181]. While pancreatectomy was successful in inducing GDM, it was performed prior to pregnancy, which does not accurately reflect the development of human GDM. Pancreatectomy has also been shown to induce hyperglycemia and diabetes in healthy baboons; however, such models are rarely used in the context of pregnancy [182]. While the surgical removal of the pancreas may induce maternal diabetes during pregnancy, it is an invasive and nonspecific procedure, as it removes both the endocrine and the exocrine tissues of the pancreas [180]. This may result in potential effects not related to GDM.

\subsection{Pharmacological Models}

Pharmacological agents, including streptozotocin (STZ) and alloxan, have been used to selectively destroy the pancreatic $\beta$-cells and impair $\beta$-cell function [183,184]. Chemical agents offer a relatively easy way to generate maternal hyperglycemia and diabetes; however, there are inconsistencies in the effects of chemical agents, depending on drug delivery method, dosing, species, age, diet, and 
time of gestation at which the drug is administered. While rodents are more commonly used as models for chemical-induced diabetes studies, STZ has been used in nonhuman primates to study the effects of maternal diabetes on the offspring [185]. In female rhesus monkeys, STZ treatment induced hyperglycemia and glucose intolerance $[185,186]$. The treated animals were also found to have larger placentas and neonates, as well as a higher incidence of stillbirth [186]. While both surgical and chemical animal models have been used to reproduce GDM, neither are able to accurately simulate the conditions of human GDM. Pancreatectomy and the use of STZ and alloxan permanently remove the endocrine function of the pancreas, reducing insulin and resulting in a permanent state of diabetes. This is unlike GDM in humans, usually a transitory disease that develops as a consequence of maternal insulin resistance, compounded by increasing amounts of human placental lactogen throughout pregnancy and the inability of the maternal pancreatic $\beta$-cells to adapt [180]. It is also important to acknowledge that there can be fundamental similarities and important differences between rodents and humans regarding islet biology. For example, there is still a debate on $\beta$-cell compensation during pregnancy in rodent models vs. humans [187], because limited human autopsy studies do not consistently support the mechanisms observed in rodents.

\subsection{Diet-Induced Models}

Diet-induced models of GDM include high-fat feeding in animal models to induce insulin resistance and diabetes. A study using a high-fat diet (HFD) demonstrated that in the non-pregnant state. female rats, while obese, displayed normal glucose clearance. After successful mating with control males, pregnant females on HFD displayed hyperglycemia and glucose intolerance [188]. In another study, pregnant female rats were administered continuous glucose infusions during the last week of gestation, inducing hyperglycemia and hyperinsulinemia [189]. The offspring born to these females had phenotypes resembling those of children born to mothers with GDM. While a GDM animal model involving obesity may represent actual risk factors for human GDM, these models do not consider the genetic and social factors contributing to the development of the disease.

\subsection{Genetic Models}

Genetic models have been used to induce GDM in animals. The $\mathrm{db} / \mathrm{db}$ mouse model of leptin deficiency is currently the most widely used model of T2D. Normally, $\mathrm{db} /+$ female animals present a normal glucose homeostasis phenotype; however, during pregnancy, they develop spontaneous GDM, and pups display characteristics similar to those of infants of GDM mothers [190]. For example, the offspring of $\mathrm{db} /+$ dams with GDM exhibited obesity and insulin resistance in the liver. Another model that has been described is the prolactin receptor deficient $\left(\mathrm{PrlR}^{-/-}\right)$mouse. While $\mathrm{PrlR}^{-/-}$females were unable to carry a pregnancy to full term, $\mathrm{Prl}^{+/-}$dams exhibited hyperglycemia and failure to increase $\beta$-cell mass and proliferation during pregnancy, a necessary event to maintain euglycemia [191]. In the non-pregnant state, these female mice presented with euglycemia and decreased $\beta$-cell mass. Other genetic models that have investigated transcription factors and different key signaling pathways to induce GDM are discussed elsewhere $[180,192,193]$. Genetic models provide an opportunity to study the underlying mechanisms involved in the pathogenesis of GDM. Unfortunately, conclusions may be limited, as they are often based on single gene mutations, which do not accurately mimic the polygenetic and environmental factors contributing to human GDM.

\subsection{Fetal Programming Models}

Several novel models of GDM have been generated by using the first-generation offspring (F1) of dams (F0) from various intrauterine programming procedures. In a study using a rat model, STZ, a toxin that promotes pancreatic $\beta$-cell demise, was administered to F0 generation female pups to induce diabetes [194]. After successful mating with nondiabetic males, the female F1 pups were used to study GDM during pregnancy. They found that non-pregnant F1 pups were euglycemic but developed hyperglycemia and hyperinsulinemia during pregnancy. This suggests that exposure to a diabetic 
intrauterine environment may set up female offspring to develop GDM during pregnancy. In another study, a uteroplacental insufficiency rat model was used to generate intrauterine growth-restricted (IUGR) offspring [195]. After successful breeding of the IUGR female offspring to normal males, pregnant females demonstrated glucose impairment and insulin resistance. The offspring of these female rats exhibited increased body weight, insulin resistance, and impaired glucose clearance, eventually developing diabetes. In another mouse model, researchers used the F1 offspring born to dams fed a low-protein (LP) diet during gestation and lactation. The F1 females develop glucose intolerance and reduced $\beta$-cell proliferation during pregnancy [196]. These models demonstrated that exposure to GDM or glucose intolerance during gestation increases the susceptibility of the offspring (F1) to developing GDM.

Animal models have also been used to study the consequences of GDM on the health of the offspring. Offspring born to mothers with GDM are at increased risk for obesity, glucose intolerance, and diabetes [179]. In the previously mentioned study by Gauguier et al., in which GDM was induced in female rats by continuous glucose infusion administered during the last week of pregnancy $[189,197]$, female offspring demonstrated glucose intolerance and impaired insulin secretion. When these female offspring were mated with control males, the newborn offspring presented with hyperglycemia, hyperinsulinemia, and increased body weight, which persisted into adulthood. These studies suggest that intrauterine exposure to maternal diabetes may affect the health of more than one generation. In the intrauterine programming model of maternal gestational diabetes in rats by Boloker et al., the offspring developed glucose intolerance and impaired insulin secretion, which worsened with age [195]. The effects of maternal high-fat diet on the health of the offspring have also been studied in nonhuman primates. In female Japanese macaques, maternal high-fat diet was shown to increase liver triglycerides and increase the risk of developing nonalcoholic fatty liver disease in the offspring [198,199]. These studies provide evidence that there are lasting effects of maternal gestational diabetes on the health of the offspring.

GDM is a complex disease with genetic, environmental, and epigenetic risk factors. Therefore, it is unlikely that a single animal model will accurately represent human GDM. A realistic model may include animal models with multiple etiologies presented by GDM, which will likely include both genetic and environmental factors. Furthermore, while larger animals and nonhuman primates may be more similar to humans physiologically, studies using these animal models remain more limited compared to those on mice and rat models, due to feasibility and costs.

Nevertheless, animal models have advanced the understanding of maternal gestational diabetes beyond clinical observation alone. Furthermore, they may provide a valuable means to study intervention strategies targeting GDM in pregnant women.

\section{Concluding Remarks}

The high prevalence of GDM is a major obstacle to achieving improved maternal and child health. While GDM is a transient condition, its sequalae are lifelong, and GDM research should be a public health priority. Studies discussed in this review underscore the gravity of GDM and challenges to its management, including identifying and overcoming risk factors, accurate diagnosis, and treatment of the disease in order to prevent associated complications. We emphasized the health burden and consequences of GDM in both the mother and the baby, as well as in subsequent generations (Figure 1). We highlighted the utility of preclinical models of GDM to help us understand the underlying pathophysiology of the disease and the timely need to increase our scientific toolbox to identify strategies to prevent and treat GDM, thereby advancing clinical care. The prevalence of obesity and diabetes continues to increase worldwide and, until we can put a stop to the vicious cycle of diabetes, will continue to impose great burdens on patients, their families, and society as a whole. As depicted in Figure 1, there is a high need to prioritize preventive healthcare for pregnant women at risk for GDM. There are critical points during this vicious cycle of transgenerational obesity and diabetes which offer opportunities for intervention. We stress here that the continued study of GDM 
including its risk factors, diagnosis, and management is necessary for its understanding as well as for the prevention of metabolic disease in the offspring and for stopping the vicious cycle of diabetes.

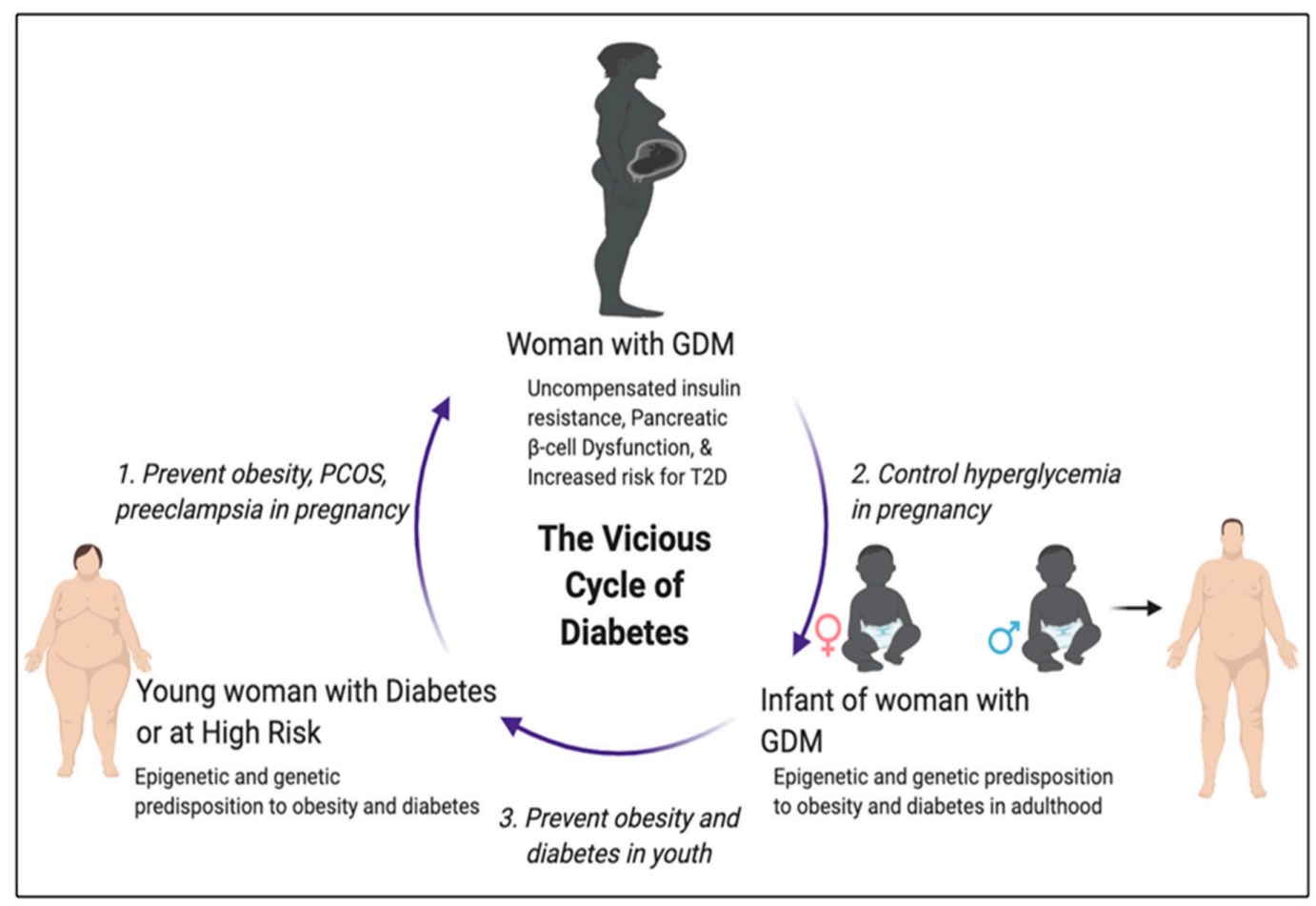

Figure 1. Gestational diabetes mellitus (GDM) is a harbinger to the vicious cycle of transgenerational obesity and diabetes. The general pathology of GDM is shown, including the three critical windows of opportunity to break the cycle. PCOS, polycystic ovary syndrome.

Funding: This research was funded by the Philippine Council for Health Research and Development - Department of Science and Technology (Grant MOA 18-0200 and 19-0663 to M.R.B.P.-C.) and the National Institutes of Health Grant NIDDK (R21-DK112144, R03-DK114465, R01-DK115720, and McKnight and IBP start-up funds to E.U.A).

Acknowledgments: We thank Eric Gustafson for technical assistance with the review. We thank Ronald Ygona for Figure 1. We thank the PCHRD Balik Scientist Program for funding support for EUA.

Conflicts of Interest: The authors declare no conflict of interest.

\section{References}

1. Hanson, M.A.; Gluckman, P.D.; Ma, R.C.; Matzen, P.; Biesma, R. Early life opportunities for prevention of diabetes in low and middle income countries. BMC Public Health 2012, 12, 1025. [CrossRef]

2. Poon, L.C.; Simmons, D.; Hyett, J.A.; Da Fonseca, E.B.; Hod, M. The first-trimester of pregnancy-A window of opportunity for prediction and prevention of pregnancy complications and future life. Diabetes Res. Clin. Pract. 2018, 145, 20-30. [CrossRef] [PubMed]

3. Catov, J.M.; Margerison-Zilko, C. Pregnancy as a window to future health: Short-term costs and consequences. Am. J. Obstet. Gynecol. 2016, 215, 406-407. [CrossRef] [PubMed]

4. Godfrey, K.M.; Barker, D.J.; Aranceta, J.; Serra-Majem, L.; Ribas, L.; Pérez-Rodrigo, C. Fetal programming and adult health. Public Health Nutr. 2001, 4, 611-624. [CrossRef]

5. Hoffman, D.; Reynolds, R.M.; Hardy, D.B. Developmental origins of health and disease: Current knowledge and potential mechanisms. Nutr. Rev. 2017, 75, 951-970. [CrossRef] [PubMed]

6. Diagnostic criteria and classification of hyperglycaemia first detected in pregnancy: A World Health Organization Guideline. Diabetes Res. Clin. Pract. 2014, 103, 341-363. [CrossRef]

7. American Diabetes Association. Diagnosis and classification of diabetes mellitus. Diabetes Care 2013, 36 (Suppl. S1), S67-S74. [CrossRef] 
8. Schneider, S.; Bock, C.; Wetzel, M.; Maul, H.; Loerbroks, A. The prevalence of gestational diabetes in advanced economies. J. Périnat. Med. 2012, 40, 511-520. [CrossRef]

9. McCance, D.R.; Maresh, M.; Sacks, D.A. A Practical Manual of Diabetes in Pregnancy; Wiley-Blackwell: Chichister, UK, 2010.

10. Plows, J.F.; Stanley, J.L.; Baker, P.N.; Reynolds, C.; Vickers, M.H. The Pathophysiology of Gestational Diabetes Mellitus. Int. J. Mol. Sci. 2018, 19, 3342. [CrossRef]

11. Parsons, J.A.; Brelje, T.C.; Sorenson, R.L. Adaptation of islets of Langerhans to pregnancy: Increased islet cell proliferation and insulin secretion correlates with the onset of placental lactogen secretion. Endocrinology 1992, 130, 1459-1466.

12. Herrera, E. Implications of Dietary Fatty Acids during Pregnancy on Placental, Fetal and Postnatal Development-A Review. Placenta 2002, 23, S9-S19. [CrossRef]

13. Svensson, H.; Wetterling, L.; Bosaeus, M.; Odén, B.; Odén, A.; Jennische, E.; Edén, S.; Holmäng, A.; Lönn, M. Body fat mass and the proportion of very large adipocytes in pregnant women are associated with gestational insulin resistance. Int. J. Obes. 2015, 40, 646-653. [CrossRef]

14. Lau, D.C. Central Role of Adipose Tissue in Pregnancy and Lactation. In Maternal-Fetal and Neonatal Endocrinology; Elsevier BV: Amsterdam, The Netherlands, 2020; pp. 147-158.

15. De Souza, L.R.; Berger, H.; Retnakaran, R.; Maguire, J.L.; Nathens, A.B.; Connelly, P.; Ray, J.G. First-Trimester Maternal Abdominal Adiposity Predicts Dysglycemia and Gestational Diabetes Mellitus in Midpregnancy. Diabetes Care 2015, 39, 61-64. [CrossRef] [PubMed]

16. Vellinga, A.; Zawiejska, A.; Harreiter, J.; Buckley, B.; Di Cianni, G.; Lapolla, A.; Corcoy, R.; Simmons, D.; Adelantado, J.M.; Damm, P.; et al. Associations of Body Mass Index (Maternal BMI) and Gestational Diabetes Mellitus with Neonatal and Maternal Pregnancy Outcomes in a Multicentre European Database (Diabetes and Pregnancy Vitamin D and Lifestyle Intervention for Gestational Diabetes Mellitus Prevention). ISRN Obes. 2012, 2012, 1-4. [CrossRef]

17. Chen, C.; Xu, X.; Yan, Y. Estimated global overweight and obesity burden in pregnant women based on panel data model. PLoS ONE 2018, 13, e0202183. [CrossRef]

18. Cypryk, K.; Pertyńska-Marczewska, M.; Szymczak, W.; Zawodniak-Szałapska, M.; Wilczyński, J.; Lewiński, A. Overweight and obesity as common risk factors for gestational diabetes mellitus (GDM), perinatal macrosomy in offspring and type-2 diabetes in mothers. Prz. Lek. 2005, 62, 38-41.

19. Miao, M.; Dai, M.; Zhang, Y.; Sun, F.; Guo, X.; Sun, G.-J. Influence of maternal overweight, obesity and gestational weight gain on the perinatal outcomes in women with gestational diabetes mellitus. Sci. Rep. 2017, 7, 305. [CrossRef]

20. Cnattingius, S.; Villamor, E.; Johansson, S.; Bonamy, A.-K.E.; Persson, M.; Wikström, A.-K.; Granath, F. Maternal Obesity and Risk of Preterm Delivery. JAMA 2013, 309, 2362-2370. [CrossRef] [PubMed]

21. Çınar, M.; Timur, H.; Aksoy, R.T.; Guzel, A.I.; Tokmak, A.; Findik, R.B.; Uygur, D. Evaluation of maternal and perinatal outcomes among overweight women who experienced stillbirth. J. Matern. Neonatal Med. 2016, 30, 1-20. [CrossRef]

22. Boney, C.M. Metabolic Syndrome in Childhood: Association With Birth Weight, Maternal Obesity, and Gestational Diabetes Mellitus. Pediatrics 2005, 115, 290-296. [CrossRef]

23. Catalano, P.M.; Shankar, K. Obesity and pregnancy: Mechanisms of short term and long term adverse consequences for mother and child. BMJ 2017, 356, 1. [CrossRef] [PubMed]

24. Rasmussen, K.M.; Abrams, B.; Bodnar, L.M.; Butte, N.F.; Catalano, P.M.; Siega-Riz, A.M. Recommendations for Weight Gain During Pregnancy in the Context of the Obesity Epidemic. Obstet. Gynecol. 2010, 116, 1191-1195. [CrossRef]

25. Morisset, A.-S.; Veillette, J.; Weisnagel, S.J.; Tchernof, A.; Robitaille, J.; St-Yves, A. Prevention of gestational diabetes mellitus: A review of studies on weight management. Diabetes Metab. Res. Rev. 2010, 26, 17-25. [CrossRef]

26. Hopkins, S.; Artal, R. The Role of Exercise in Reducing the Risks of Gestational Diabetes Mellitus. Women's Health 2013, 9, 569-581. [CrossRef] [PubMed]

27. Qi, Y.; Sun, X.; Tan, J.; Zhang, G.; Chen, M.; Xiong, Y.; Chen, P.; Liu, C.; Zou, K.; Liu, X. Excessive gestational weight gain in the first and second trimester is a risk factor for gestational diabetes mellitus among women pregnant with singletons: A repeated measures analysis. J. Diabetes Investig. 2020. [CrossRef] [PubMed] 
28. Wani, K.; Sabico, S.; Alnaami, A.M.; Al-Musharaf, S.; Fouda, M.A.; Turkestani, I.Z.; Al-Ajlan, A.; Alshingetti, N.M.; Alokail, M.S.; Al-Daghri, N.M. Early-Pregnancy Metabolic Syndrome and Subsequent Incidence in Gestational Diabetes Mellitus in Arab Women. Front. Endocrinol. 2020, 11, 98. [CrossRef]

29. Chatzi, L.; Plana, E.; Pappas, A.; Alegkakis, D.; Karakosta, P.; Daraki, V.; Vassilaki, M.; Tsatsanis, C.; Kafatos, A.; Koutis, A.; et al. The metabolic syndrome in early pregnancy and risk of gestational diabetes mellitus. Nutr. Ther. Interv. Diabetes Metab. Syndr. 2009, 35, 490-494. [CrossRef]

30. Shin, D.; Lee, K.W.; Song, W.O. Dietary Patterns during Pregnancy Are Associated with Risk of Gestational Diabetes Mellitus. Nutrients 2015, 7, 9369-9382. [CrossRef]

31. Sedaghat, F.; Akhoondan, M.; Ehteshami, M.; Aghamohammadi, V.; Ghanei, N.; Mirmiran, P.; Rashidkhani, B. Maternal Dietary Patterns and Gestational Diabetes Risk: A Case-Control Study. J. Diabetes Res. 2017, 2017, 1-8. [CrossRef]

32. Moses, R.G.; Brand-Miller, J. Dietary risk factors for gestational diabetes mellitus: Are sugar-sweetened soft drinks culpable or guilty by association? Diabetes Care 2009, 32, 2314-2315. [CrossRef]

33. Saraf-Bank, S.; Tehrani, H.G.; Haghighatdoost, F.; Moosavian, S.P.; Azadbakht, L. The acidity of early pregnancy diet and risk of gestational diabetes mellitus. Clin. Nutr. 2018, 37, 2054-2059. [CrossRef]

34. WHO. Diet, Nutrition and the Prevention of Chronic Diseases; WHO Technical Report Series, No. 916 (TRS 916); WHO: Geneva, Switzerland, 2003.

35. Vickers, M.H.; Sloboda, D.M. Strategies for Reversing the Effects of Metabolic Disorders Induced as a Consequence of Developmental Programming. Front. Physiol. 2012, 3, 242. [CrossRef] [PubMed]

36. Mooi, N.; Ncama, B.P. Evidence on nutritional therapy practice guidelines and implementation in adult critically ill patients: A systematic scoping review. Curationis 2019, 42, e1-e13. [CrossRef] [PubMed]

37. Weickert, M.O.; Möhlig, M.; Koebnick, C.; Holst, J.J.; Namsolleck, P.; Ristow, M.; Osterhoff, M.; Rochlitz, H.; Rudovich, N.; Spranger, J.; et al. Impact of cereal fibre on glucose-regulating factors. Diabetology 2005, 48, 2343-2353. [CrossRef] [PubMed]

38. Zhang, C.; Liu, S.; Solomon, C.G.; Hu, F.B. Dietary Fiber Intake, Dietary Glycemic Load, and the Risk for Gestational Diabetes Mellitus. Diabetes Care 2006, 29, 2223-2230. [CrossRef]

39. Brand-Miller, J.; Colagiuri, S.; Crossman, S.; Allen, A.; Roberts, D.C.; Truswell, A.S. Low-Glycemic Index Foods Improve Long-Term Glycemic Control in NIDDM. Diabetes Care 1991, 14, 95-101. [CrossRef]

40. Shyam, S.; Arshad, F.; Ghani, R.A.; Wahab, N.A.; Safii, N.S.; Yusof, B.N.M.; Chinna, K.; Kamaruddin, N.A. Low glycaemic index diets improve glucose tolerance and body weight in women with previous history of gestational diabetes: A six months randomized trial. Nutr. J. 2013, 12, 68. [CrossRef]

41. Pitsavos, C.; Panagiotakos, D.B.; Weinem, M.; Stefanadis, C. Diet, Exercise and the Metabolic Syndrome. Rev. Diabet. Stud. 2006, 3, 118-126. [CrossRef]

42. Filardi, T.; Panimolle, F.; Crescioli, C.; Lenzi, A.; Morano, S. Gestational Diabetes Mellitus: The Impact of Carbohydrate Quality in Diet. Nutrients 2019, 11, 1549. [CrossRef]

43. Luoto, R.; Laitinen, K.; Nermes, M.; Isolauri, E. Impact of maternal probiotic-supplemented dietary counselling on pregnancy outcome and prenatal and postnatal growth: A double-blind, placebo-controlled study. Br. J. Nutr. 2010, 103, 1792-1799. [CrossRef]

44. Furness, J.B.; Rivera, L.R.; Cho, H.-J.; Bravo, D.M.; Callaghan, B. The gut as a sensory organ. Nat. Rev. Gastroenterol. Hepatol. 2013, 10, 729-740. [CrossRef]

45. Isolauri, E.; Rautava, S.; Collado, M.C.; Salminen, S. Role of probiotics in reducing the risk of gestational diabetes. Diabetes Obes. Metab. 2015, 17, 713-719. [CrossRef] [PubMed]

46. Kalra, B.; Gupta, Y.; Singla, R.; Kalra, S. Use of Oral Anti-Diabetic Agents in Pregnancy: A Pragmatic Approach. N. Am. J. Med. Sci. 2015, 7, 6-12. [CrossRef]

47. Harris, H.R.; Babic, A.; Webb, P.M.; Nagle, C.M.; Jordan, S.J.; Risch, H.A.; Rossing, M.A.; Doherty, J.A.; Goodman, M.T.; Modugno, F.; et al. Polycystic Ovary Syndrome, Oligomenorrhea, and Risk of Ovarian Cancer Histotypes: Evidence from the Ovarian Cancer Association Consortium. Cancer Epidemiol. Biomark. Prev. 2017, 27, 174-182. [CrossRef]

48. Pasquali, R.; Zanotti, L.; Fanelli, F.; Mezzullo, M.; Fazzini, A.; Morselli-Labate, A.M.; Repaci, A.; Ribichini, D.; Gambineri, A. Defining Hyperandrogenism in Women With Polycystic Ovary Syndrome: A Challenging Perspective. J. Clin. Endocrinol. Metab. 2016, 101, 2013-2022. [CrossRef]

49. Dunaif, A. Insulin resistance and the polycystic ovary syndrome: Mechanism and implications for pathogenesis. Endocr. Rev. 1997, 18, 774-800. [PubMed] 
50. Bhathena, R.K. Insulin resistance and the long-term consequences of polycystic ovary syndrome. J. Obstet. Gynaecol. 2011, 31, 105-110. [CrossRef] [PubMed]

51. Mustaniemi, S.; Vääräsmäki, M.; Eriksson, J.G.; Gissler, M.; Laivuori, H.; Ijäs, H.; Bloigu, A.; Kajantie, E.; Morin-Papunen, L. Polycystic ovary syndrome and risk factors for gestational diabetes. Endocr. Connect. 2018, 7, 859-869. [CrossRef]

52. Li, G.; Huang, W.; Zhang, L.; Tian, Z.; Zheng, W.; Wang, T.; Zhang, T.; Zhang, W. A prospective cohort study of early-pregnancy risk factors for gestational diabetes in polycystic ovarian syndrome. Diabetes Metab. Res. Rev. 2018, 34, e3003. [CrossRef]

53. Lo, J.C.; Feigenbaum, S.L.; Escobar, G.J.; Yang, J.; Crites, Y.M.; Ferrara, A. Increased Prevalence of Gestational Diabetes Mellitus Among Women With Diagnosed Polycystic Ovary Syndrome: A population-based study. Diabetes Care 2006, 29, 1915-1917. [CrossRef]

54. Norman, R.J.; Davies, M.; Lord, J.; Moran, L.J. The role of lifestyle modification in polycystic ovary syndrome. Trends Endocrinol. Metab. 2002, 13, 251-257. [CrossRef]

55. Douglas, C.C.; Gower, B.A.; Darnell, B.E.; Ovalle, F.; Oster, R.; Azziz, R. Role of diet in the treatment of polycystic ovary syndrome. Fertil. Steril. 2006, 85, 679-688. [CrossRef] [PubMed]

56. Radosh, L. Drug treatments for polycystic ovary syndrome. Am. Fam. Physician 2009, 79, 671-676.

57. Jeyabalan, A. Epidemiology of preeclampsia: Impact of obesity. Nutr. Rev. 2013, 71, S18-S25. [CrossRef] [PubMed]

58. Cho, G.J.; Kim, H.Y.; Park, J.H.; Ahn, K.-H.; Hong, S.-C.; Kim, H.-J.; Han, S.W.; Oh, M.-J. Prepregnancy Factors Are Associated with Development of Hypertension Later in Life in Women with Pre-Eclampsia. J. Women's Health 2019, 28, 984-989. [CrossRef]

59. Gutaj, P.; Zawiejska, A.; Mantaj, U.; Wender-Ożegowska, E. Determinants of preeclampsia in women with type 1 diabetes. Acta Diabetol. 2017, 54, 1115-1121. [CrossRef] [PubMed]

60. Hedderson, M.; Ferrara, A. High Blood Pressure Before and During Early Pregnancy is Associated with an Increased Risk of Gestational Diabetes Mellitus. Diabetes Care 2008, 31, 2362-2367. [CrossRef]

61. Lee, J.; Ouh, Y.-T.; Ahn, K.H.; Hong, S.C.; Oh, M.-J.; Kim, H.-J.; Cho, G.J. Preeclampsia: A risk factor for gestational diabetes mellitus in subsequent pregnancy. PLoS ONE 2017, 12, e0178150. [CrossRef] [PubMed]

62. Kitzmiller, J.L.; Block, J.M.; Brown, F.M.; Catalano, P.M.; Conway, D.L.; Coustan, D.R.; Gunderson, E.P.; Herman, W.H.; Hoffman, L.D.; Inturrisi, M.; et al. Managing Preexisting Diabetes for Pregnancy: Summary of evidence and consensus recommendations for care. Diabetes Care 2008, 31, 1060-1079. [CrossRef] [PubMed]

63. Horsch, A.; Kang, J.S.; Vial, Y.; Ehlert, U.; Borghini, A.; Marques-Vidal, P.; Jacobs, I.; Puder, J.J. Stress exposure and psychological stress responses are related to glucose concentrations during pregnancy. $\mathrm{Br}$. J. Health Psychol. 2016, 21, 712-729. [CrossRef] [PubMed]

64. Myoga, M.; Japan Environment and Children's Study; Tsuji, M.; Tanaka, R.; Shibata, E.; Askew, D.J.; Aiko, Y.; Senju, A.; Kawamoto, T.; Hachisuga, T.; et al. Impact of sleep duration during pregnancy on the risk of gestational diabetes in the Japan environmental and Children's study (JECS). BMC Pregnancy Childbirth 2019, 19, 1-7. [CrossRef] [PubMed]

65. Hosler, A.S.; Nayak, S.; Radigan, A.M. Stressful events, smoking exposure and other maternal risk factors associated with gestational diabetes mellitus. Paediatr. Périnat. Epidemiol. 2011, 25, 566-574. [CrossRef]

66. Loeken, M.R. Passive smoking as an independent risk factor for gestational diabetes that synergizes with prepregnancy obesity in urban Chinese women. Diabetes Metab. Res. Rev. 2017, 33, e2910. [CrossRef]

67. Lee, K.W.; Ching, S.M.; Ramachandran, V.; Yee, A.; Hoo, F.K.; Chia, Y.C.; Sulaiman, W.A.W.; Suppiah, S.; Mohamed, M.H.; Veettil, S.K. Prevalence and risk factors of gestational diabetes mellitus in Asia: A systematic review and meta-analysis. BMC Pregnancy Childbirth 2018, 18, 494. [CrossRef]

68. Larrabure-Torrealva, G.; Martinez, S.; Luque-Fernández, M.-Á.; Sanchez, S.E.; Mascaro-Sánchez, P.; Ingar, H.; Castillo, W.; Zumaeta, R.; Grande, M.; Motta, V.; et al. Prevalence and risk factors of gestational diabetes mellitus: Findings from a universal screening feasibility program in Lima, Peru. BMC Pregnancy Childbirth 2018, 18, 303. [CrossRef] [PubMed]

69. Abu-Heija, A.; Al-Bash, M.R.; Al-Kalbani, M.A. Effects of maternal age, parity and pre-pregnancy body mass index on the glucose challenge test and gestational diabetes mellitus. J. Taibah Univ. Med. Sci. 2017, 12, 338-342. [CrossRef]

70. Mishra, S.; Shetty, A.; Rao, C.R.; Nayak, S.; Kamath, A. Risk factors for gestational diabetes mellitus: A prospective case-control study from coastal Karnataka. Clin. Epidemiol. Glob. Health 2020. [CrossRef] 
71. Li, Y.; Ren, X.; He, L.; Li, J.; Zhang, S.; Chen, W. Maternal age and the risk of gestational diabetes mellitus: A systematic review and meta-analysis of over 120 million participants. Diabetes Res. Clin. Pract. 2020, 162, 108044. [CrossRef] [PubMed]

72. Lin, P.-C.; Hung, C.; Ke, L.-Y.; Lin, K.-C.; Hsu, Y.-Y.; Tzeng, Y.-L. The risk factors for gestational diabetes mellitus: A retrospective study. Midwifery 2016, 42, 16-20. [CrossRef]

73. Souza De Oliveira Dode, M.A.; Dos Santos, I.S. Non classical risk factors for gestational diabetes mellitus: A systematic review of the literature. Cad. Saúde Pública 2009, 25, S341-S359. [CrossRef]

74. Wan, C.S.; Abell, S.; Aroni, R.; Nankervis, A.; Boyle, J.; Teede, H.J. Ethnic differences in prevalence, risk factors, and perinatal outcomes of gestational diabetes mellitus: A comparison between immigrant ethnic Chinese women and Australian-born Caucasian women in Australia. J. Diabetes 2019, 11, 809-817. [CrossRef]

75. Pedula, K.L.; Hillier, T.A.; Schmidt, M.M.; Mullen, J.A.; Charles, M.A.; Pettitt, D.J. Ethnic differences in gestational oral glucose screening in a large US population. Ethn. Dis. 2009, 19, 414-419.

76. Hall, L.M.L.; Moran, C.N.; Milne, G.R.; Wilson, J.; Macfarlane, N.G.; Forouhi, N.G.; Hariharan, N.; Salt, I.P.; Sattar, N.; Gill, J.M. Fat Oxidation, Fitness and Skeletal Muscle Expression of Oxidative/Lipid Metabolism Genes in South Asians: Implications for Insulin Resistance? PLoS ONE 2010, 5, e14197. [CrossRef] [PubMed]

77. Kim, D.S.; Kim, B.C.; Daily, J.; Park, S. High genetic risk scores for impaired insulin secretory capacity doubles the risk for type 2 diabetes in Asians and is exacerbated by Western-type diets. Diabetes Metab. Res. Rev. 2017, 34, e2944. [CrossRef]

78. Lowe, W.L.; Scholtens, D.; Sandler, V.; Hayes, M.G.; Lowe, W.L. Genetics of Gestational Diabetes Mellitus and Maternal Metabolism. Curr. Diabetes Rep. 2016, 16, 15. [CrossRef]

79. Lauenborg, J.; Grarup, N.; Damm, P.; Borch-Johnsen, K.; Jørgensen, T.; Pedersen, O.; Hansen, T. Common Type 2 Diabetes Risk Gene Variants Associate with Gestational Diabetes. J. Clin. Endocrinol. Metab. 2009, 94, 145-150. [CrossRef] [PubMed]

80. Watanabe, R.M.; Allayee, H.; Xiang, A.H.; Trigo, E.; Hartiala, J.; Lawrence, J.M.; Buchanan, T.A. Transcription factor 7-like 2 (TCF7L2) is associated with gestational diabetes mellitus and interacts with adiposity to alter insulin secretion in Mexican Americans. Diabetes 2007, 56, 1481-1485. [CrossRef] [PubMed]

81. Papadopoulou, A.; Lynch, K.F.; Shaat, N.; Hakansson, R.; Ivarsson, S.A.; Berntorp, K.; Agardh, C.D.; Lernmark, Å. DiPiS Study Group Gestational diabetes mellitus is associated with TCF7L2 gene polymorphisms independent of HLA-DQB1*0602 genotypes and islet cell autoantibodies. Diabet. Med. 2011, 28, 1018-1027. [CrossRef]

82. Vejražková, D.; Lukasova, P.; Vanková, M.; Vcelák, J.; Bradnova, O.; Cirmanova, V.; Andelova, K.; Krejci, H.; Bendlova, B. MTNR1B Genetic Variability Is Associated with Gestational Diabetes in Czech Women. Int. J. Endocrinol. 2014, 2014, 1-7. [CrossRef]

83. Vlassi, M.; Gazouli, M.; Paltoglou, G.; Christopoulos, P.; Florentin, L.; Kassi, G.; Mastorakos, G. The rs10830963 variant of melatonin receptor MTNR1B is associated with increased risk for gestational diabetes mellitus in a Greek population. Hormones 2012, 11, 70-76. [CrossRef]

84. Kwak, S.H.; Kim, S.-H.; Cho, Y.M.; Go, M.J.; Cho, Y.S.; Choi, S.H.; Moon, M.K.; Jung, H.S.; Shin, H.D.; Kang, H.M.; et al. A Genome-Wide Association Study of Gestational Diabetes Mellitus in Korean Women. Diabetes 2012, 61, 531-541. [CrossRef] [PubMed]

85. Wang, K.; Chen, Q.; Feng, Y.; Yang, H.; Wu, W.; Zhang, P.; Wang, Y.; Ko, J.; Zhao, F.; Du, W.; et al. Single Nucleotide Polymorphisms in CDKAL1 Gene Are Associated with Risk of Gestational Diabetes Mellitus in Chinese Population. J. Diabetes Res. 2019, 2019, 3618103-3618107. [CrossRef]

86. Fatima, S.S.; Chaudhry, B.; Khan, T.A.; Farooq, S. KCNQ1 rs2237895 polymorphism is associated with Gestational Diabetes in Pakistani Women. Pak. J. Med Sci. 2016, 32, 1380-1385. [CrossRef]

87. Shin, H.D.; Park, B.L.; Shin, H.J.; Kim, J.Y.; Park, S.; Kim, B.; Kim, S.-H. Association ofKCNQ1Polymorphisms with the Gestational Diabetes Mellitus in Korean Women. J. Clin. Endocrinol. Metab. 2010, 95, 445-449. [CrossRef] [PubMed]

88. Alharbi, K.K.; Khan, I.A.; Abotalib, Z.; Al-Hakeem, M.M. Insulin Receptor Substrate-1 (IRS-1) Gly927Arg: Correlation with Gestational Diabetes Mellitus in Saudi Women. BioMed Res. Int. 2014, 2014, 1-5. [CrossRef] [PubMed]

89. Tok, E.C.; Ertunc, D.; Bilgin, O.; Erdal, E.M.; Kaplanoğlu, M.; Dilek, S.; Erdal, M.E. Association of insulin receptor substrate-1 G972R variant with baseline characteristics of the patients with gestational diabetes mellitus. Am. J. Obstet. Gynecol. 2006, 194, 868-872. [CrossRef] [PubMed] 
90. Yahaya, T.; Anyebe, D. Genes predisposing to neonatal diabetes mellitus and pathophysiology: Current findings. J. Neonatal-Perinatal Med. 2020, 1-11. [CrossRef]

91. Lehnen, H.; Zechner, U.; Haaf, T. Epigenetics of gestational diabetes mellitus and offspring health: The time for action is in early stages of life. Mol. Hum. Reprod. 2013, 19, 415-422. [CrossRef] [PubMed]

92. Ding, G.-L.; Huang, H.-F. Paternal transgenerational glucose intolerance with epigenetic alterations in second generation offspring of GDM. Asian J. Androl. 2013, 15, 451-452. [CrossRef] [PubMed]

93. Litwin, L.; Sundholm, J.K.M.; Rönö, K.; Koivusalo, S.B.; Eriksson, J.G.; Sarkola, T. Transgenerational effects of maternal obesity and gestational diabetes on offspring body composition and left ventricle mass: The Finnish Gestational Diabetes Prevention Study (RADIEL) 6-year follow-up. Diabet. Med. 2019, 37, 147-156. [CrossRef]

94. Franzago, M.; Fraticelli, F.; Stuppia, L.; Vitacolonna, E. Nutrigenetics, epigenetics and gestational diabetes: Consequences in mother and child. Epigenetics 2019, 14, 215-235. [CrossRef]

95. Huang, T.; Shu, Y.; Cai, Y. Genetic differences among ethnic groups. BMC Genom. 2015, 16, 1-10. [CrossRef] [PubMed]

96. Yuan, V.; Price, E.M.; Del Gobbo, G.; Mostafavi, S.; Cox, B.J.; Binder, A.M.; Michels, K.B.; Marsit, C.J.; Robinson, W.P. Accurate ethnicity prediction from placental DNA methylation data. Epigenet. Chromatin 2019, 12. [CrossRef] [PubMed]

97. Carolan, M.; Davey, M.-A.; Biro, M.A.; Kealy, M. Maternal age, ethnicity and gestational diabetes mellitus. Midwifery 2012, 28, 778-783. [CrossRef] [PubMed]

98. Jenum, A.K.; Mørkrid, K.; Sletner, L.; Vange, S.; Torper, J.L.; Nakstad, B.; Voldner, N.; Rognerud-Jensen, O.H.; Berntsen, S.; Mosdøl, A.; et al. Impact of ethnicity on gestational diabetes identified with the WHO and the modified International Association of Diabetes and Pregnancy Study Groups criteria: A population-based cohort study. Eur. J. Endocrinol. 2012, 166, 317-324. [CrossRef] [PubMed]

99. Robitaille, J.; Grant, A. The genetics of gestational diabetes mellitus: Evidence for relationship with type 2 diabetes mellitus. Genet. Med. 2008, 10, 240-250. [CrossRef]

100. Yu, X.; Wang, Q.; Qin, L.; Peng, L.; Chen, Z.; Qin, X.; Wang, Y.; Shi, Q.; Yu, H. Association between a functional polymorphism rs10830963 in melatonin receptor 1B and risk of gestational diabetes mellitus: An updated meta-analysis. bioRxiv 2017. [CrossRef]

101. Park, H.; He, A.; Lodhi, I.J. Lipid Regulators of Thermogenic Fat Activation. Trends Endocrinol. Metab. 2019, 30, 710-723. [CrossRef]

102. Kajimura, S.; Spiegelman, B.; Seale, P. Brown and Beige Fat: Physiological Roles beyond Heat Generation. Cell Metab. 2015, 22, 546-559. [CrossRef]

103. Celi, F.S.; Brychta, R.J.; Linderman, J.D.; Butler, P.W.; Alberobello, A.T.; Smith, S.; Courville, A.B.; Lai, E.W.; Costello, R.; Skarulis, M.C.; et al. Minimal changes in environmental temperature result in a significant increase in energy expenditure and changes in the hormonal homeostasis in healthy adults. Eur. J. Endocrinol. 2010, 163, 863-872. [CrossRef]

104. Wolf, K.; Schneider, A.; Breitner, S.; Von Klot, S.; Meisinger, C.; Cyrys, J.; Hymer, H.; Wichmann, H.-E.; Peters, A.; for the Cooperative Health Research in the Region of Augsburg (KORA) Study Group. Air Temperature and the Occurrence of Myocardial Infarction in Augsburg, Germany. Circulation 2009, 120 , 735-742. [CrossRef]

105. Shi, L.; Kloog, I.; Zanobetti, A.; Liu, P.; Schwartz, J. Impacts of temperature and its variability on mortality in New England. Nat. Clim. Chang. 2015, 5, 988-991. [CrossRef] [PubMed]

106. Vasileiou, V.; Kyratzoglou, E.; Paschou, S.A.; Kyprianou, M.; Anastasiou, E. The impact of environmental temperature on the diagnosis of gestational diabetes mellitus. Eur. J. Endocrinol. 2018, 178, 209-214. [CrossRef] [PubMed]

107. Price, L.A.; Lock, L.J.; Archer, L.E.; Ahmed, Z. Awareness of Gestational Diabetes and its Risk Factors among Pregnant Women in Samoa. Hawai'i J. Med. Public Health 2017, 76, 48-54.

108. Ansarzadeh, S.; Salehi, L.; Mahmoodi, Z.; Mohammadbeigi, A. Factors affecting the quality of life in women with gestational diabetes mellitus: A path analysis model. Health Qual. Life Outcomes 2020, 18, 1-9. [CrossRef]

109. Ogu, R.N.; Maduka, O.; Agala, V.; Alamina, F.; Adebiyi, O.; Edewor, U.; Porbeni, I.; Abam, C. Gestational Diabetes Mellitus Knowledge Among Women of Reproductive Age in Southern Nigeria: Implications for Diabetes Education. Int. Q. Community Health Educ. 2019, 40, 177-183. [CrossRef] [PubMed] 
110. Rönö, K.; Masalin, S.; Kautiainen, H.; Gissler, M.; Raina, M.; Eriksson, J.G.; Kainulainen, H. Impact of maternal income on the risk of gestational diabetes mellitus in primiparous women. Diabet. Med. 2019, 36, 214-220. [CrossRef]

111. Nelson, K.M.; Chapko, M.K.; Reiber, G.; Boyko, E.J. The Association between Health Insurance Coverage and Diabetes Care; Data from the 2000 Behavioral Risk Factor Surveillance System. Health Serv. Res. 2005, 40, 361-372. [CrossRef]

112. Hsu, C.-C.; Lee, C.-H.; Wahlqvist, M.L.; Huang, H.-L.; Chang, H.-Y.; Chen, L.; Shih, S.-F.; Shin, S.-J.; Tsai, W.-C.; Chen, T.; et al. Poverty Increases Type 2 Diabetes Incidence and Inequality of Care Despite Universal Health Coverage. Diabetes Care 2012, 35, 2286-2292. [CrossRef]

113. Petkova, V.; Dimitrov, M.; Geourgiev, S. Pilot project for education of gestational diabetes mellitus (GDM) patients-Can it be beneficial? Afr. J. Pharm. Pharmacol. 2011, 5, 1282-1286. [CrossRef]

114. Alayoub, H.; Curran, S.; Coffey, M.; Hatunic, M.; Higgins, M.F. Assessment of the effectiveness of group education on knowledge for women with newly diagnosed gestational diabetes. Ir. J. Med Sci. 2017, 187, 65-68. [CrossRef] [PubMed]

115. Minschart, C.; Amuli, K.; Delameillieure, A.; Calewaert, P.; Mathieu, C.; Benhalima, K. Multidisciplinary Group Education for Gestational Diabetes Mellitus: A Prospective Observational Cohort Study. J. Clin. Med. 2020, 9, 509. [CrossRef] [PubMed]

116. Mirfeizi, M.; Tourzani, Z.M.; Jafarabadi, M.A.; Hanjani, S.M.; Hasanzad, M. Health education in gestational diabetes mellitus and quality of life. J. Midwifery Reprod. Health 2017, 5, 1066-1074.

117. Caughey, A.B.; Turrentine, M. ACOG Practice Bulletin No. 190 Summary: Gestational Diabetes Mellitus. Obstet. Gynecol. 2018, 131, 406-408.

118. Rani, P.R.; Begum, J. Screening and Diagnosis of Gestational Diabetes Mellitus, Where Do We Stand. J. Clin. Diagn. Res. 2016, 10, QE01-QE04. [CrossRef]

119. McIntyre, H.D.; Colagiuri, S.; Roglic, G.; Hod, M. Diagnosis of GDM: A suggested consensus. Best Pract. Res. Clin. Obstet. Gynaecol. 2015, 29, 194-205. [CrossRef]

120. Hosseini, E.; Janghorbani, M.; Aminorroaya, A. Incidence, risk factors, and pregnancy outcomes of gestational diabetes mellitus using one-step versus two-step diagnostic approaches: A population-based cohort study in Isfahan, Iran. Diabetes Res. Clin. Pract. 2018, 140, 288-294. [CrossRef]

121. Akgol, S.; Obut, M.; Kahveci, B.; Budak, M.S.; Baglı, I. An Evaluation of the Effect of a One or Two-Step Gestational Diabetes Mellitus Screening Program on Obstetric and Neonatal Outcomes in Pregnancies. Gynecol. Obstet. Reprod. Med. 2018, 25, 1-5. [CrossRef]

122. Burtis, C.A.; Bruns, D.E. Tietz Fundamentals of Clinical Chemistry and Molecular Diagnostics, 7th ed.; Elsevier: St. Louis, MI, USA, 2015.

123. Luewan, S.; Bootchaingam, P.; Tongsong, T. Comparison of the Screening Tests for Gestational Diabetes Mellitus between "One-Step" and "Two-Step" Methods among Thai Pregnant Women. Obstet. Gynecol. Int. 2018, 2018, 1-5. [CrossRef]

124. Berghella, V.; Caissutti, C.; Saccone, G.; Khalifeh, A. One-Step Approach to Identifying Gestational Diabetes Mellitus. Obstet. Gynecol. 2019, 133, 383. [CrossRef]

125. Brown, J.; Alwan, N.A.; West, J.; Brown, S.; McKinlay, C.; Farrar, D.; Crowther, C.A. Lifestyle interventions for the treatment of women with gestational diabetes. Cochrane Database Syst. Rev. 2017, 2017, 959. [CrossRef]

126. Celen, S.; Yildiz, Y.; Kahyaoglu, S.; Kaymak, O.; Ozel, M.; Timur, H.; Danişman, N. Cost-Effectivity Analysis of One-Step Versus Two-Step Screening for Gestational Diabetes. Eurasian J. Med. 2012, 44, 84-87. [CrossRef] [PubMed]

127. Meltzer, S.J.; Snyder, J.; Penrod, J.; Nudi, M.; Morin, L. Gestational diabetes mellitus screening and diagnosis: A prospective randomised controlled trial comparing costs of one-step and two-step methods. BJOG Int. J. Obstet. Gynaecol. 2010, 117, 407-415. [CrossRef] [PubMed]

128. Nankervis, A.; McIntyre, H.D.; Moses, R.G.; Ross, G.P.; Callaway, L.K. Testing for Gestational Diabetes Mellitus in Australia. Diabetes Care 2013, 36, e64. [CrossRef]

129. Diabetes Canada Clinical Practice Guidelines Expert Committee; Feig, D.S.; Berger, H.; Donovan, L.; Godbout, A.; Kader, T.; Keely, E.; Sanghera, R. Diabetes and Pregnancy. Can. J. Diabetes 2018, 42 (Suppl. S1), S255-S282. 
130. Kleinwechter, H.; Schäfer-Graf, U.; Bührer, C.; Hoesli, I.; Kainer, F.; Kautzky-Willer, A.; Pawlowski, B.; Schunck, K.; Somville, T.; Sorger, M. Gestational Diabetes Mellitus (GDM) Diagnosis, Therapy and Follow-Up Care. Exp. Clin. Endocrinol. Diabetes 2014, 122, 395-405. [CrossRef]

131. Vitacolonna, E.; Succurro, E.; Lapolla, A.; Scavini, M.; Bonomo, M.; Di Cianni, G.; Di Benedetto, A.; Napoli, A.; Tumminia, A.; Festa, C.; et al. Guidelines for the screening and diagnosis of gestational diabetes in Italy from 2010 to 2019: Critical issues and the potential for improvement. Acta Diabetol. 2019, 56, 1159-1167. [CrossRef]

132. Metzger, B.E.; Lowe, L.P.; Dyer, A.R.; Trimble, E.R.; Chaovarindr, U.; Coustan, D.R.; Hadden, D.R.; McCance, D.; Hod, M.; McIntyre, H.D.; et al. Hyperglycemia and Adverse Pregnancy Outcomes. N. Engl. J. Med. 2008, 358, 1991-2002. [CrossRef]

133. Behboudi-Gandevani, S.; Amiri, M.; Yarandi, R.B.; Tehrani, F.R. The impact of diagnostic criteria for gestational diabetes on its prevalence: A systematic review and meta-analysis. Diabetol. Metab. Syndr. 2019, 11, 1-18. [CrossRef]

134. Weinert, L.S. International Association of Diabetes and Pregnancy Study Groups recommendations on the diagnosis and classification of hyperglycemia in pregnancy: Comment to the International Association of Diabetes and Pregnancy Study Groups Consensus Panel. Diabetes Care 2010, 33, e97. [CrossRef]

135. Schmidt, M.I.; Duncan, B.B.; Reichelt, A.J.; Branchtein, L.; Matos, M.C.; Forti, A.C.E.; Spichler, E.R.; Pousada, J.M.; Teixeira, M.M.; Yamashita, T. Gestational diabetes mellitus diagnosed with a 2-h 75-g oral glucose tolerance test and adverse pregnancy outcomes. Diabetes Care 2001, 24, 1151-1155. [CrossRef] [PubMed]

136. Lehmann, R.; Troendle, A.; Brandle, M. New insights into diagnosis and management of gestational diabetes mellitus: Recommendations of the Swiss Society for Endocrinology and Diabetes. Ther. Umsch. 2009, 66, 695-706. [CrossRef] [PubMed]

137. Cortel, M.R.B.P.; Manalo, M.E.M.; Canivel, R.R.C.; Matias, R.S.; Dizon, A.J.B.; Bacani, M.N.S.; Dalmacio, J.S.B. Screening and Diagnosis of Gestational Diabetes Mellitus Using 75-g Oral Glucose Tolerance Test Following the WHO, ADA, and IADPSG Criteria. J. Diabetes Metab. 2018, 9, 1-4. [CrossRef]

138. Stanley, J.; Cheung, C.C.; Rueda-Clausen, C.; Sankaralingam, S.; Baker, P.N.; Davidge, S.T. Effect of Gestational Diabetes on Maternal Artery Function. Reprod. Sci. 2011, 18, 342-352. [CrossRef]

139. Dharmashankar, K.; Widlansky, M.E. Vascular Endothelial Function and Hypertension: Insights and Directions. Curr. Hypertens. Rep. 2010, 12, 448-455. [CrossRef]

140. Sullivan, S.D.; Umans, J.G.; Ratner, R.E. Gestational Diabetes: Implications for Cardiovascular Health. Curr. Diabetes Rep. 2011, 12, 43-52. [CrossRef]

141. Powe, C.E.; Levine, R.J.; Karumanchi, S.A. Preeclampsia, a disease of the maternal endothelium: The role of antiangiogenic factors and implications for later cardiovascular disease. Circulation 2011, 123, 2856-2869. [CrossRef]

142. Weissgerber, T.; Mudd, L.M. Preeclampsia and diabetes. Curr. Diabetes Rep. 2015, 15, 9-579. [CrossRef]

143. Miao, Z.; Wu, H.; Ren, L.; Bu, N.; Jiang, L.; Yang, H.; Zhang, J.; Guo, X. Long-Term Postpartum Outcomes of Insulin Resistance and beta-cell Function in Women with Previous Gestational Diabetes Mellitus. Int. J. Endocrinol. 2020, 2020, 7417356. [CrossRef]

144. Rayanagoudar, G.; Hashi, A.A.; Zamora, J.; Khan, K.S.; Hitman, G.; Thangaratinam, S. Quantification of the type 2 diabetes risk in women with gestational diabetes: A systematic review and meta-analysis of 95,750 women. Diabetology 2016, 59, 1403-1411. [CrossRef]

145. Chivese, T.; Norris, S.A.; Levitt, N.S. Progression to type 2 diabetes mellitus and associated risk factors after hyperglycemia first detected in pregnancy: A cross-sectional study in Cape Town, South Africa. PLoS Med. 2019, 16, e1002865. [CrossRef] [PubMed]

146. Eades, C.; Styles, M.; Leese, G.P.; Cheyne, H.; Evans, J.M.M. Progression from gestational diabetes to type 2 diabetes in one region of Scotland: An observational follow-up study. BMC Pregnancy Childbirth 2015, 15, 11. [CrossRef]

147. Noctor, E.; Dunne, F.P. Type 2 diabetes after gestational diabetes: The influence of changing diagnostic criteria. World J. Diabetes 2015, 6, 234-244. [CrossRef] [PubMed]

148. Herath, H.; Herath, R.P.; Wickremasinghe, R. Gestational diabetes mellitus and risk of type 2 diabetes 10 years after the index pregnancy in Sri Lankan women-A community based retrospective cohort study. PLoS ONE 2017, 12, e0179647. [CrossRef] [PubMed] 
149. Coustan, D.R. Recurrent GDM and the development of type 2 diabetes have similar risk factors. Endocrine 2016, 53, 624-625. [CrossRef]

150. Kruse, A.; Darling, M.S.; Hansen, M.K.L.; Markman, M.J.; Lauszus, F.; Wielandt, H.B. Recurrence of gestational diabetes in primiparous women. Acta Obstet. Gynecol. Scand. 2015, 94, 1367-1372. [CrossRef]

151. Wang, Y.-Y.; Liu, Y.; Li, C.; Lin, J.; Liu, X.-M.; Sheng, J.-Z.; Huang, H.-F. Frequency and risk factors for recurrent gestational diabetes mellitus in primiparous women: A case control study. BMC Endocr. Disord. 2019, 19, 1-7. [CrossRef]

152. Kc, K.; Shakya, S.; Zhang, H. Gestational Diabetes Mellitus and Macrosomia: A Literature Review. Ann. Nutr. Metab. 2015, 66, 14-20. [CrossRef]

153. Illsley, N.; Baumann, M.U. Human placental glucose transport in fetoplacental growth and metabolism. Biochim. Biophys. Acta Mol. Basis Dis. 2020, 1866, 165359. [CrossRef]

154. Yoon, M.-S. The Role of Mammalian Target of Rapamycin (mTOR) in Insulin Signaling. Nutrients 2017, 9, 1176. [CrossRef]

155. Rosario, F.J.; Powell, T.L.; Jansson, T. Activation of placental insulin and mTOR signaling in a mouse model of maternal obesity associated with fetal overgrowth. Am. J. Physiol. Integr. Comp. Physiol. 2016, 310, R87-R93. [CrossRef] [PubMed]

156. Dimasuay, K.G.; Boeuf, P.; Powell, T.L.; Jansson, T. Placental Responses to Changes in the Maternal Environment Determine Fetal Growth. Front. Physiol. 2016, 7, 2759. [CrossRef] [PubMed]

157. Hart, B.; Morgan, E.; Alejandro, E.U. Nutrient sensor signaling pathways and cellular stress in fetal growth restriction. J. Mol. Endocrinol. 2019, 62, R155-R165. [CrossRef] [PubMed]

158. Catalano, P.M.; Mouzon, S.H.-D. Is it time to revisit the Pedersen hypothesis in the face of the obesity epidemic? Am. J. Obstet. Gynecol. 2011, 204, 479-487. [CrossRef] [PubMed]

159. Castillo-Castrejon, M.; Powell, T.L. Placental Nutrient Transport in Gestational Diabetic Pregnancies. Front. Endocrinol. 2017, 8, 306. [CrossRef]

160. Logan, K.M.; Gale, C.; Hyde, M.; Santhakumaran, S.; Modi, N. Diabetes in pregnancy and infant adiposity: Systematic review and meta-analysis. Arch. Dis. Child. Fetal Neonatal Ed. 2016, 102, F65-F72. [CrossRef] [PubMed]

161. Sovio, U.; Murphy, H.R.; Smith, G.C. Accelerated Fetal Growth Prior to Diagnosis of Gestational Diabetes Mellitus: A Prospective Cohort Study of Nulliparous Women. Diabetes Care 2016, 39, 982-987. [CrossRef]

162. Dunn, A.B.; Hanson, L.; VandeVusse, L.; Leslie, S. Through the Microbial Looking Glass. J. Périnat. Neonatal Nurs. 2019, 33, 35-51. [CrossRef]

163. Chawanpaiboon, S.; Vogel, J.P.; Moller, A.-B.; Lumbiganon, P.; Petzold, M.; Hogan, D.; Landoulsi, S.; Jampathong, N.; Kongwattanakul, K.; Laopaiboon, M.; et al. Global, regional, and national estimates of levels of preterm birth in 2014: A systematic review and modelling analysis. Lancet Glob. Health 2018, 7 , e37-e46. [CrossRef]

164. Rozance, P.J.; Hay, W.W. Hypoglycemia in Newborn Infants: Features Associated with Adverse Outcomes. Neonatology 2006, 90, 74-86. [CrossRef]

165. Sweet, C.B.; Grayson, S.; Polak, M. Management Strategies for Neonatal Hypoglycemia. J. Pediatr. Pharmacol. Ther. 2013, 18, 199-208. [CrossRef]

166. Pettitt, D.J.; Baird, H.R.; Aleck, K.A.; Bennett, P.H.; Knowler, W.C. Excessive Obesity in Offspring of Pima Indian Women with Diabetes during Pregnancy. N. Engl. J. Med. 1983, 308, 242-245. [CrossRef] [PubMed]

167. Franks, P.W.; Looker, H.C.; Kobes, S.; Touger, L.; Tataranni, P.A.; Hanson, R.L.; Knowler, W.C. Gestational Glucose Tolerance and Risk of Type 2 Diabetes in Young Pima Indian Offspring. Diabetes 2006, 55, 460-465. [CrossRef] [PubMed]

168. Scholtens, D.M.; Kuang, A.; Lowe, L.P.; Hamilton, J.K.; Lawrence, J.M.; Lebenthal, Y.; Brickman, W.J.; Clayton, R.; Ma, R.C.; McCance, D.; et al. Hyperglycemia and Adverse Pregnancy Outcome Follow-up Study (HAPO FUS): Maternal Glycemia and Childhood Glucose Metabolism. Diabetes Care 2019, 42, 381-392. [CrossRef] [PubMed]

169. Keely, E.; Malcolm, J.C.; Hadjiyannakis, S.; Gaboury, I.; Lough, G.; Lawson, M.L. Prevalence of metabolic markers of insulin resistance in offspring of gestational diabetes pregnancies. Pediatr. Diabetes 2007, 9, 53-59. [CrossRef] [PubMed] 
170. Boerschmann, H.; Pflüger, M.; Henneberger, L.; Ziegler, A.-G.; Hummel, S. Prevalence and Predictors of Overweight and Insulin Resistance in Offspring of Mothers with Gestational Diabetes Mellitus. Diabetes Care 2010, 33, 1845-1849. [CrossRef] [PubMed]

171. Blotsky, A.L.; Rahme, E.; Dahhou, M.; Nakhla, M.; Dasgupta, K. Gestational diabetes associated with incident diabetes in childhood and youth: A retrospective cohort study. Can. Med Assoc. J. 2019, 191, E410-E417. [CrossRef]

172. Clausen, T.D.; Mathiesen, E.R.; Hansen, T.; Pedersen, O.; Jensen, D.M.; Lauenborg, J.; Damm, P. High Prevalence of Type 2 Diabetes and Pre-Diabetes in Adult Offspring of Women With Gestational Diabetes Mellitus or Type 1 Diabetes: The role of intrauterine hyperglycemia. Diabetes Care 2007, 31, 340-346. [CrossRef]

173. Vohr, B.R.; Boney, C.M. Gestational diabetes: The forerunner for the development of maternal and childhood obesity and metabolic syndrome? J. Matern. Neonatal Med. 2008, 21, 149-157. [CrossRef]

174. Tam, W.H.; Ma, R.C.; Ozaki, R.; Li, A.M.; Chan, M.H.M.; Yuen, L.Y.; Lao, T.T.H.; Yang, X.; Ho, C.S.; Tutino, G.E.; et al. In Utero Exposure to Maternal Hyperglycemia Increases Childhood Cardiometabolic Risk in Offspring. Diabetes Care 2017, 40, 679-686. [CrossRef]

175. Pathirana, M.M.; Lassi, Z.S.; Roberts, C.T.; Andraweera, P. Cardiovascular risk factors in offspring exposed to gestational diabetes mellitus in utero: Systematic review and meta-analysis. J. Dev. Orig. Health Dis. 2020. [CrossRef] [PubMed]

176. Leybovitz-Haleluya, N.; Wainstock, T.; Landau, D.; Sheiner, E. Maternal gestational diabetes mellitus and the risk of subsequent pediatric cardiovascular diseases of the offspring: A population-based cohort study with up to 18 years of follow up. Acta Diabetol. 2018, 55, 1037-1042. [CrossRef]

177. Yu, Y.; Arah, O.A.; Liew, Z.; Cnattingius, S.; Olsen, J.; Sørensen, H.T.; Qin, G.; Li, J. Maternal diabetes during pregnancy and early onset of cardiovascular disease in offspring: Population based cohort study with 40 years of follow-up. BMJ 2019, 367, 16398. [CrossRef]

178. Monteiro, L.J.; Norman, J.E.; Rice, G.E.; Illanes, S.E. Fetal programming and gestational diabetes mellitus. Placenta 2016, 48, S54-S60. [CrossRef]

179. Catalano, P.M. The impact of gestational diabetes and maternal obesity on the mother and her offspring. J. Dev. Orig. Health Dis. 2010, 1, 208-215. [CrossRef] [PubMed]

180. Pasek, R.; Gannon, M. Advancements and challenges in generating accurate animal models of gestational diabetes mellitus. Am. J. Physiol. Metab. 2013, 305, E1327-E1338. [CrossRef] [PubMed]

181. Jawerbaum, A.; Catafau, J.; Gonzales, E.; Rodríguez, R.; Gelpi, E.; Gomez, G.; Gimeno, A.; Gimeno, M. Eicosanoid production by uterine strips and by embryos obtained from diabetic pregnant rats. Prostaglandins 1993, 45, 487-495. [CrossRef]

182. Gillman, J.; Gilbert, C.; Epstein, E.; Allan, J.C. Endocrine Control of Blood Sugar, Lipaemia, and Ketonaemia in Diabetic Baboons. BMJ 1958, 2, 1260-1263. [CrossRef]

183. Junod, A.; Lambert, A.E.; Stauffacher, W.; Renold, A.E. Diabetogenic action of streptozotocin: Relationship of dose to metabolic response. J. Clin. Investig. 1969, 48, 2129-2139. [CrossRef]

184. Lenzen, S.; Panten, U. Alloxan: History and mechanism of action. Diabetology 1988, 31, 337-342. [CrossRef]

185. Kemnitz, J.; Eisele, S.; Lindsay, K.; Engle, M.; Perelman, R.; Farrell, P. Changes in food intake during menstrual cycles and pregnancy of normal and diabetic rhesus monkeys. Diabetology 1984, 26, 60-64. [CrossRef] [PubMed]

186. Mintz, D.H.; Chez, R.A.; Hutchinson, D.L. Subhuman Primate Pregnancy Complicated by Streptozotocin-Induced Diabetes Mellitus. J. Clin. Investig. 1972, 51, 837-847. [CrossRef] [PubMed]

187. Genevay, M.; Pontes, H.; Meda, P. Beta cell adaptation in pregnancy: A major difference between humans and rodents? Diabetology 2010, 53, 2089-2092. [CrossRef] [PubMed]

188. Holemans, K.; Caluwaerts, S.; Poston, L.; Van Assche, F. Diet-induced obesity in the rat: A model for gestational diabetes mellitus. Am. J. Obstet. Gynecol. 2004, 190, 858-865. [CrossRef] [PubMed]

189. Gauguier, D.; Bihoreau, M.T.; Picon, L.; Ktorza, A. Insulin Secretion in Adult Rats After Intrauterine Exposure to Mild Hyperglycemia During Late Gestation. Diabetes 1991, 40, 109-114. [CrossRef] [PubMed]

190. Yamashita, H.; Shao, J.; Qiao, L.; Pagliassotti, M.; Friedman, J.E. Effect of spontaneous gestational diabetes on fetal and postnatal hepatic insulin resistance in Lepr(db/+) mice. Pediatr. Res. 2003, 53, 411-418. [CrossRef]

191. Huang, C.; Snider, F.; Cross, J.C. Prolactin Receptor Is Required for Normal Glucose Homeostasis and Modulation of $\beta$-Cell Mass during Pregnancy. Endocrinology 2009, 150, 1618-1626. [CrossRef] [PubMed] 
192. Pereira, T.J.; Moyce, B.L.; Kereliuk, S.; Dolinsky, V.W. Influence of maternal overnutrition and gestational diabetes on the programming of metabolic health outcomes in the offspring: Experimental evidence. Biochem. Cell Biol. 2015, 93, 438-451. [CrossRef]

193. Jawerbaum, A.; White, V. Animal Models in Diabetes and Pregnancy. Endocr. Rev. 2010, 31, 680-701. [CrossRef] [PubMed]

194. Capobianco, E.; Fornes, D.D.; Linenberg, I.; Powell, T.L.; Jansson, T.; Jawerbaum, A. A novel rat model of gestational diabetes induced by intrauterine programming is associated with alterations in placental signaling and fetal overgrowth. Mol. Cell. Endocrinol. 2016, 422, 221-232. [CrossRef]

195. Boloker, J.; Gertz, S.J.; Simmons, R.A. Gestational diabetes leads to the development of diabetes in adulthood in the rat. Diabetes 2002, 51, 1499-1506. [CrossRef]

196. Szlapinski, S.K.; King, R.T.; Retta, G.; Yeo, E.; Strutt, B.J.; Hill, D. A mouse model of gestational glucose intolerance through exposure to a low protein diet during fetal and neonatal development. J. Physiol. 2019, 597, 4237-4250. [CrossRef]

197. Gauguier, D.; Bihoreau, M.T.; Ktorza, A.; Berthault, M.F.; Picon, L. Inheritance of diabetes mellitus as consequence of gestational hyperglycemia in rats. Diabetes 1990, 39, 734-739. [CrossRef] [PubMed]

198. McCurdy, C.E.; Bishop, J.M.; Williams, S.M.; Grayson, B.E.; Smith, M.S.; Friedman, J.E.; Grove, K.L. Maternal high-fat diet triggers lipotoxicity in the fetal livers of nonhuman primates. J. Clin. Investig. 2009, 119, $323-335$. [CrossRef] [PubMed]

199. Friedman, J.E. Obesity and Gestational Diabetes Mellitus Pathways for Programming in Mouse, Monkey, and Man-Where Do We Go Next? The 2014 Norbert Freinkel Award Lecture. Diabetes Care 2015, 38, 1402-1411. [CrossRef] [PubMed]

(C) 2020 by the authors. Licensee MDPI, Basel, Switzerland. This article is an open access article distributed under the terms and conditions of the Creative Commons Attribution (CC BY) license (http://creativecommons.org/licenses/by/4.0/). 